\title{
THE PHOSPHATE NUTRITION OF WHITE CLOVER
}

\author{
R. S. Sсотт \\ Invermay Agricultural Research Centre, MAF, Mosgiet
}

\section{A bstract}

The high phosphate requirements of grass/clover pastures are discussed in relation to the greater efficiency of grasses compared with clovers in extracting limited amounts of available soil P. Results of experiments are briefly described which show that variation in response to applied $\mathrm{P}$ exists within the white clover species. It is suggested that the emphasis of research effort should be shifted from its present preoccupation with the determination of $\mathrm{P}$ requirements of soils to that of selecting and breeding cultivars which have lower soil $\mathrm{P}$ requirements than do cultivars now available. This approach could provide a means of reducing dependence on heavy phosphate topdressing.

\section{INTRODUCTION}

IT Is COMMON KNowLEDge that New Zealand's grass/clover pastures are dependent upon the stimulation of clover growth by phosphate topdressing in order that clovers may fix adequate nitrogen for use by associated grasses. The purpose of this paper is to consider whether variability exists in the efficiency of $\mathrm{P}$ nutrition within the species white clover (Trifolium repens) to enable breeding programmes which could reduce dependence on phosphate topdressing.

\section{Competitive Abiliti of Clovers}

There is evidence in many field experiments dating back to the pioneering work of Trumble and Shapter (1937) in Australia to show that clovers cannot compete successfully with grasses for scarce $P$.

In a paper presented to a previous meeting of this Association, Jackman and Mouat (1973) showed that browntop (Agrostis lenuis) can reduce the amount of $\mathrm{P}$ which is available to white clover by direct root competition and by decreasing soil moisture levels-and hence availability of-?. In Australia-, Barrow-(1975ab) has shown that Wimmera ryegrass (Lolium rigidum) has a lower soil $\mathrm{P}$ requirement than subterranean clover (Trifolium subterraneum) for near-maximum yields through its greater ability to extract $\mathrm{P}$ from the soil. This he attributed to the larger surface area of ryegrass roots and to their greater ability to reduce the soil $\mathrm{P}$ concentration at the root surface. 
Fitrting the SoIL to the Plant

In simplest terms, the foregoing means that, by raising the amount of available $\mathrm{P}$ in the soil above the requirements of the grasses, sufficient $\mathrm{P}$ is available to meet the requirements of white clover. Thus it can be said that the philosophy on which New Zealand's grass/clover economy is based is, that of fitting the soil (by topdressing) to meet the $\mathrm{P}$ requirements of white clover.

Fitting the Plant to The SOIL

There is an alternative philosophy which has received scant attention - fitting the clover plant to the soil (either in its natural state or with a minimum of topdressing) by selecting and breeding clovers which have lower soil $\mathrm{P}$ requirements. In times of rising fertilizer prices this offers an attractive approach. The type of plant required is one which combines the attributes of present cultivars (Fig. 1) with the ability to give large yield responses to small additions of $P$.

There is adequate evidence obtained from a number of plant species to show that yield response to the major plant nutrients is under genetic control (Vose, 1963; Gerloff, 1963; Epstein, 1963, 1972; Bernard and Howell, 1964). In the case of white clover present evidence is limited. In the U.K., Snaydon and Bradshaw (1962) found that white clover populations from soils

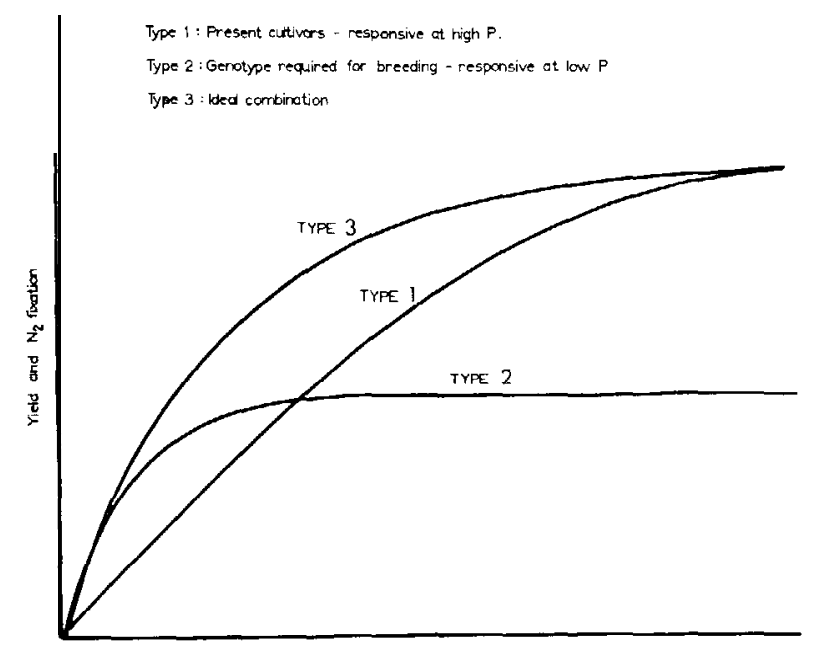

Pant avaloble $\mathrm{P}$

FIc. 1: Illustration of extremesi in typess of yield responses to applied $P$ by white clovers and an ideal combination of genotypes between these two extremes. 
low in $\mathrm{P}$ did not respond to $\mathrm{P}$ as much as populations from soils high in P. Recent work by Brock and Hoglund (1974) has shown inter-cultivar differences in which 'Grasslands Pitau' made relatively more root growth than 'Grasslands Huia' under low levels of $\mathrm{P}$. These findings raise hope for progress in breeding white clover which requires less topdressing with phosphatic fertilizers in order to maintain present levels of pasture production.

A brief account will be given of results of some experiments (Scott, 1976) investigating variation in yield responses to applied $P$ between cultivars of white clover.

\section{EXPERIMENTAL AND RESULTS}

The experiments were conducted in pots using a soil deficient in P (an untopdressed Tokomaru silt loam with a "Quick-test" Truog $\mathrm{P}$ value of 2) which was mixed with one-third by weight of fine sand. Phosphorus was applied as sodium dihydrogen phosphate at levels up to $240 \mathrm{~kg} \mathrm{P} / \mathrm{ha}$, calculated on a surface area basis, and mixed with the soil/sand. Adequate basal dressings of potassium, sulphur and molybdenum were applied.

From an initial screening experiment two cultivars which appeared to differ in their response to applied $\mathrm{P}$ were selected for detailed study. These were 'Grasslands Huia' and 'Tamar culture type' (ex Netherlands) white clovers. Plants were grown from germinated seedlings for a period of 74 and 76 days in Experiments 1 and 2, respectively, before harvesting.

EXPERIMENT 1

This experiment compared herbage yield responses of Huia and Tamar to increasing levels of applied $\mathrm{P}$, their $\mathrm{N}_{2}$-fixing activity, $\mathrm{P}$ absorption, and U utilization. They were compared under three simulated climates - a hot and dry summer climate of Tara Hills on the MacKenzie basin, a warm and moist spring climate of Palmerston North, and a cold and moist winter climate of the Taieri Plains.

Tamar gave higher overall yields $(P<0.01)$ than Huia in the three climates. and significantly outyielded Huia at $100 \mathrm{~kg}$ P/ha under both the Tara Hills and Taieri climates (Fig. 2). Under the former climate there was a cultivar $X$ quadratic interaction $(P<0.05)$ which occurred because of the positive curvature in yield response of Tamar compared with a negative response curve from Huia.

Nitrogen fixing activity (measured by acetylene reduction assay) did not differ between cultivars as the level of applied $\mathrm{P}$ was increased. 

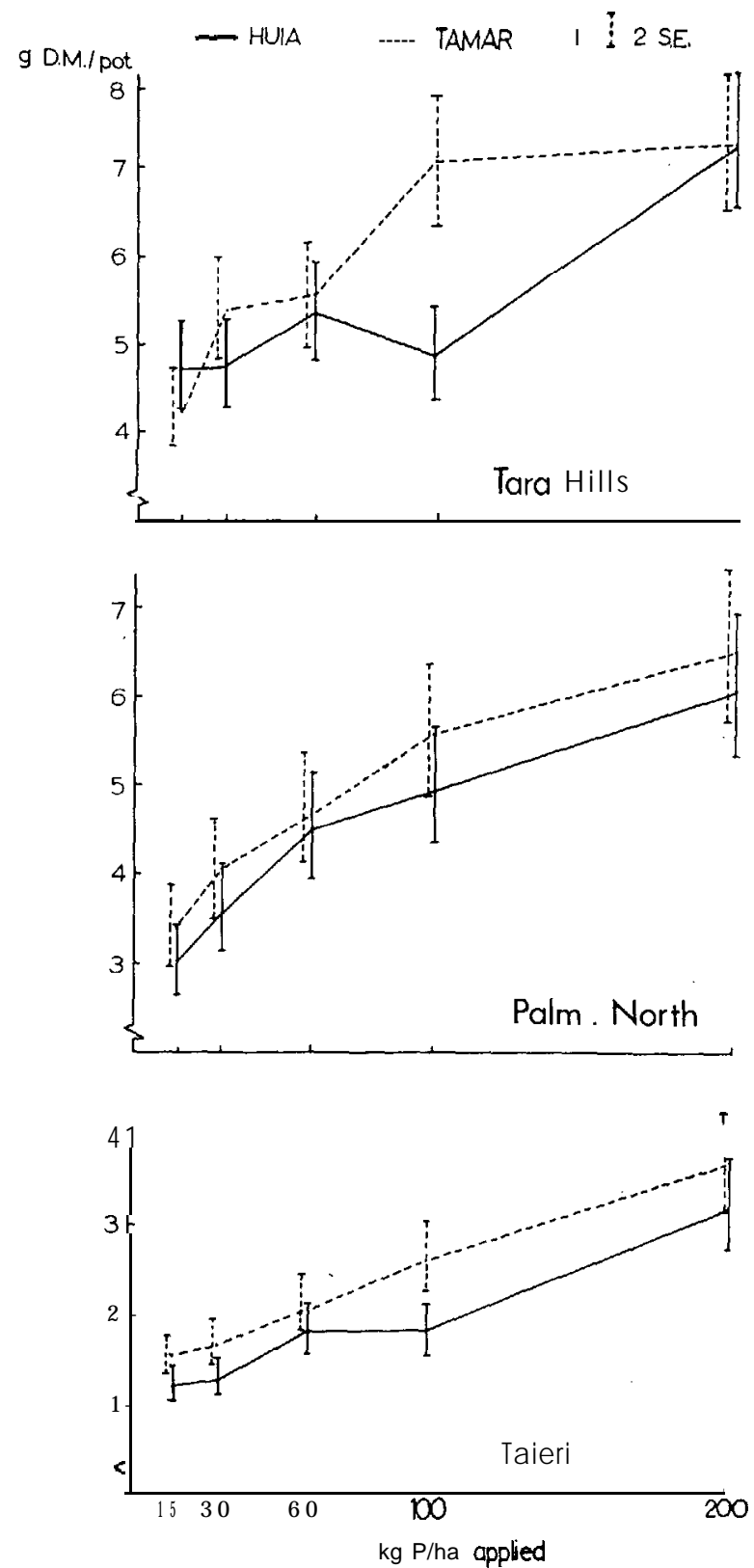

Fig. 2: Herbage dry matter yields according lo level of applied P, showing natural values retransformed from natural logarithms, as analysed Experiment 1. 
Differences in yield response between the two cultivars could not be explained in terms of total amounts of $\mathrm{P}$ absorbed (roots + shoots) by the cultivars. Their mean absorption was inconsistent between climates, although there was a suggestion in the data that absorption was greater by Tamar than Huia at $100 \mathrm{~kg}$ $\mathrm{P} /$ ha (Table 1). Mean utilization of $\mathrm{P}$ by shoots was greater for Tamar than for Huia, but there was no significant interaction to show that $P$ utilization changed with increases in the level of $\mathrm{P}$ applied under all climates (Table 2).

Although no cause for the differences in response to $\mathrm{P}$ were identified, results did show some variation. However, roots of both cultivars were observed to contain a small infestation of root knot nematodes (Meliodogyne hapla) which could have exerted a more adverse effect on Huia than on Tamar and could account for the negative curvature of the response surface of Huia. For this reason the experiment was repeated with the same two cultivars.

\section{EXPERIMENT 2}

The cultivars were examined under four climates (all combinations of high and low light intensities and temperatures). Nematodes were removed from the soil by sterilization with methyl bromide. For brevity, only the results from the mean of all four climates will be described.

TABLE 1: TOTAL P ABSORPTION BY HUIA AND TAMAR WHITE CI.OVER - EXPERIMENT 1 (mg/pot)

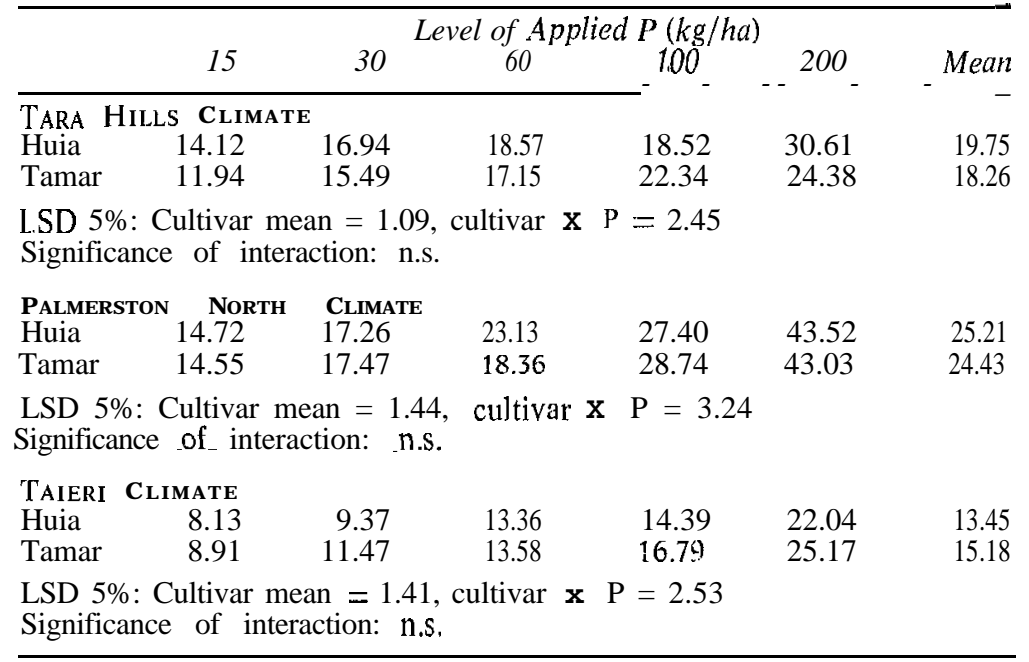


TABLE 2: UTILIZATION OF $P$ IN HERBAGE OF HUIA AND TAMAR WHITE CLOVER - EXPERIMENT 1 (g DM/g P absorbed)

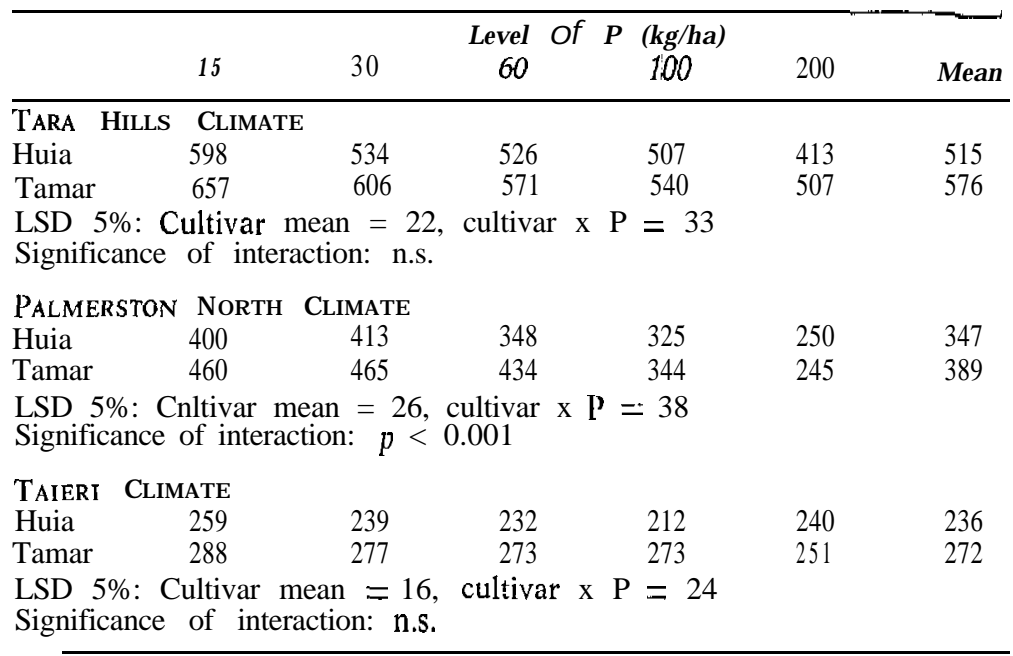

TABLE 3: NITROGEN-FIXING ACTIVITY OF HUIA AND TAMAR WHITE CLOVER MEASURED BY ACETYLENE REDUCTION ASSAY - EXPERIMENT 2

(micromoles ethylene produced/pot over a 4-hour period)

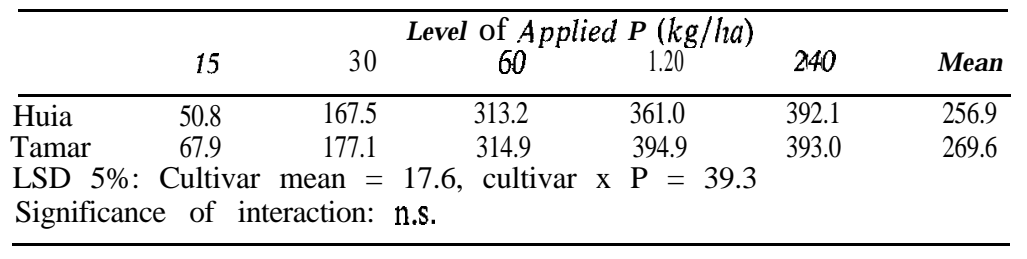

TABLE 4: TOTAL P ABSORPTION AND UTILIZATION BY HUIA AND TAMAR WHITE CLOVER — EXPERIMENT 2

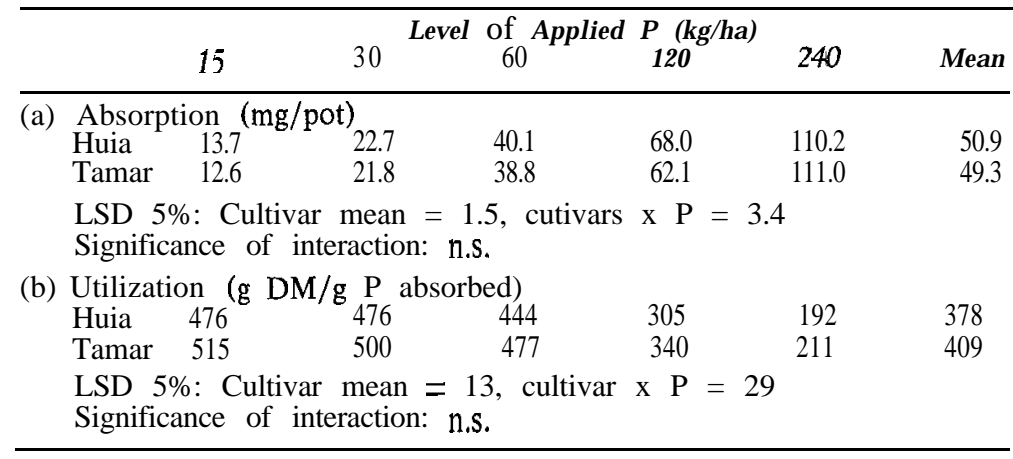


Total yields (shoots + roots) were significantly greater $(P<$ 0.001) for Tamar than for Huia, and within the levels of $P$ Tamar significantly outyielded Huia at $240 \mathrm{~kg} \mathrm{P} / \mathrm{ha}$ (Fig. 3). A significant interaction $(P=0.02)$ indicated that differences were increasing with each increment in applied $P$.

Mean $\mathrm{N}_{2}$-fixing activity did not differ between cultivars and, although no interaction with level of $\mathrm{P}$ was recorded, the higher value for Tamar at $120 \mathrm{~kg}$ P/ha approached significance (Table 3).

Mean absorption of $\mathrm{P}$ (shoots + roots) was greater for Huia and the difference between cultivars did not change as the level of $\mathrm{P}$ was increased (Table 4a). Tamar had a significantly higher utilization of $\mathrm{P}$ (shoots + roots) overall and at all but the $240 \mathrm{~kg}$ $\mathrm{P} / \mathrm{ha}$ level; there was no significant interaction with level of $\mathrm{P}$ (Table 4b).

From results of the two experiments there is no clear evidence to indicate that Tamar absorbed more $\mathrm{P}$ than Huia at high levels of applied P. Therefore, absorption cannot be considered to have been the cause of the greater yield response of Tamar.

Utilization of $\mathrm{P}$ was greater for Tamar in both experiments. The evidence did not show differences to be greatest at high levels of $\mathrm{P}$ where yield responses of Tamar were greatest. Howver, it was considered that, if utilization of $\mathrm{P}$ by Tamar was higher, then it must be better able to remobilize $\mathrm{P}$ within the

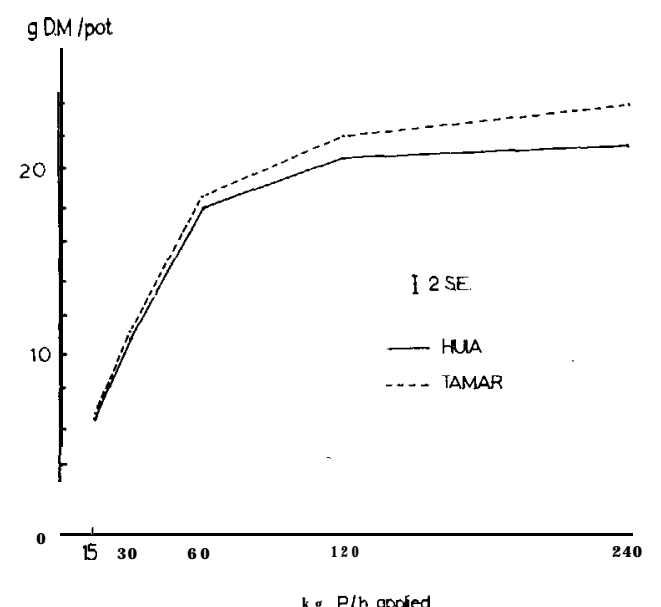

FIG. 3: Yields of dry matter (shoots + roots) of Huia and Tamar white cl over in response to applied $\mathrm{P}$ - Experiment 2. 


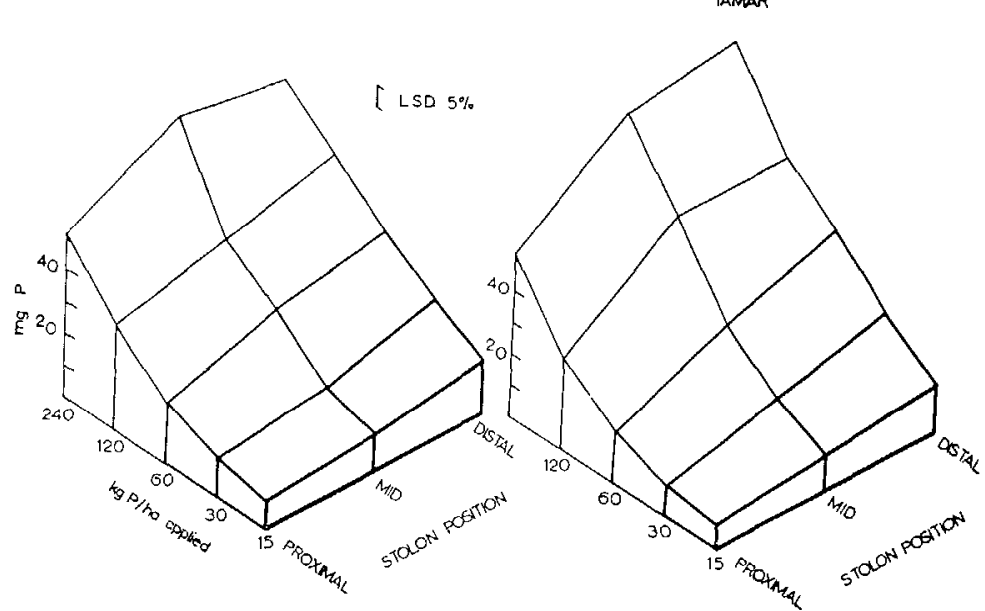

FIG. 4: The effects of applied $P$ on fhe $P$ content of nodes + internodes + laminae + pefioles of Huia and Tamar white clover at different posiiions along the stolon - Experimenf 2.

plant from older to younger tissue where growth occurs. This was investigated by examining the amount of $\mathrm{P}$ in different parts of the stolons of the two cultivars. Stolon nodes, internodes, and laminae and petioles were removed from the proximal end of the stolons where older and senescing tissue is located, from the mid-stolon region, and from the distal end of the stolon where the actively growing tissue is present. Results (Fig. 4) showed a marked increase in the proportion of $\mathrm{P}$ in the actively growing compared with the senescing tissue in Tamar at $240 \mathrm{~kg} \mathrm{P} / \mathrm{ha}$. Huia did not show a similar change. These results suggest that Tamar had a greater propensity to mobilize $\mathrm{P}$ within the plants to actively growing tissue. A further treatment (details of which will not be presented) which placed the plants under $\mathrm{P}$ stress (by imposing 48 hours' dark) also showed that Tamar was better able to mobilize $\mathrm{P}$ to its meristematic tissue.

\section{DISCUSSION}

Both experiments have shown Tamar to be a higher yielding cultivar than Huia and more responsive to high levels of applied P. Results of the second experiment provide a more reliable account of yield responses of the two cultivars as response curves of similar shapes and with similar differences have been reproduced in a recent experiment conducted on a different soil (a sterilized Warepa silt loam). 
The results do not provide clear reasons for differences in yield response to applied $\mathrm{P}$ between the two cultivars. They could not be accounted for in terms of amounts of $\mathrm{P}$ absorbed. However, there is evidence that utilization of $\mathrm{P}$ by Tamar was greater, as was its ability to mobilize $\mathrm{P}$ within the stolon to actively growing tissue. This ability was greatest at $240 \mathrm{~kg} \mathrm{P} / \mathrm{ha}$ - the level at which yield differences were greatest in Experiment 2. It is therefore suggested that higher utilization resulting from a greater propensity to mobilize $\mathrm{P}$ could account for the yield differences recorded.

At the outset it was pointed out that a clover is required which is more responsive than Huia at low levels of available P. From a practical viewpoint it is unfortunate that the cultivar selected for detailed comparison with Huia subsequently proved more responsive to high rather than low levels of applied P. Nevertheless, the experiments demonstrate that variability in response to $\mathrm{P}$ exists within the species. Thus there appear to be reasonable prospects for litting the white clover plant to soils with lower levels of available $\mathrm{P}$ as a means of reducing dependence on heavy phosphate topdressing.

\section{ACKNOWLEDGEMENTS}

The author wishes to express his gratitude to Professor B. R. Watkin, Agronomy Department, Massey University, and to Dr R. H. Jackman, formerly at Grasslands Division, Palmerston North, for guidance in the experiments. The assistance of A. Hardacre, Plant Physiology Division, Palmerston North, in the conduct of the second experiment is also gratefully acknowledged.

\section{REFERENCES}

Barrow, N. I., 1975a. Aust. I. agric. Res., 26: 137-43. 1975b. Ibid., 26: 145-56.

Bernard, R. L.; Howell, R. W., 1964. Crop Sci.. 4: 298-9.

Brock, J. L.; Hoglund, J. H., 1974. N.Z. Ml agric. Res., 17: 47-63.

Epstein, E., 1963. Natn. Acad. Sci. Natn. Counc, Publ. 942: 284-98. 1972. Mineral N utrition of Plants: Principles and Perspectives. Wiley, New York

Gerloff, G. C., 1963. A. Rev. Physiol., 14: 107-24.

Jackman, R. W.; Mouat, M. C. H., 1973. Proc. N.Z. Grassld A SS., 35: 95-100.

Scott, R. S., 1976. Massey University Ph.D. thesis (copy lodged Massey University, Palmerston North).

Snaydon, R. W.; Bradshaw, A. D., 1962. J. exp. Bot., 13: 422-34.

Trumble, H. C.; Shapter, A. A. C. I., 1937. Bull. Counc. scient. ind. Res. Melb., 105 (2): 25-36.

Vose, P. B., 1963. Herb. Abstr., 33: I-13. 